Eur. J. Clin. Chem. Clin. Biochem.

Vol. 30, 1992, pp. $171-178$

(C) 1992 Walter de Gruyter \& Co. Berlin · New York

\title{
Three Types of Naturally Occurring Modified Lipoproteins Induce Intracellular Lipid Accumulation in Human Aortic Intimal Cells - The Role of Lipoprotein Aggregation
}

By V.V. Tertov ${ }^{1}$, I. A. Sobenin ${ }^{1}$, Z. A. Gabbasov ${ }^{1}$, E. G. Popov ${ }^{2}$, A. A. Yaroslavov ${ }^{2}$, M. Jauhiainen $^{3}$, C. Ehnholm ${ }^{3}, V$. N. Smirnov ${ }^{1}$ and A. N. Orekhov ${ }^{1}$

1 Institute of Experimental Cardiology, USSR Cardiology Research Center, Moscow, Russia

2 Dept. of Chemistry, Moscow State University, Moscow, Russia

3 National Public Health Institute, Department of Biochemistry, Helsinki, Finland

(Received September 13, 1991/February 5, 1992)

\begin{abstract}
Summary: Blood monocytes or intimal smooth muscle cells from normal aorta were incubated with low density lipoprotein (LDL) from patients with coronary atherosclerosis, or with LDL from diabetic patients, or with lipoprotein(a) $(\mathrm{Lp}(\mathrm{a}))$. In each case there was a 2- to 4-fold rise in the intracellular cholesteryl ester content. LDL from healthy subjects failed to induce intracellular lipid accumulation in these cells. LDL from patients with coronary atherosclerosis, LDL from diabetic patients, and $\mathrm{Lp}(\mathrm{a})$ form aggregates under cell culture conditions. The ability of these lipoproteins to increase the cholesteryl ester content of cultured cells is directly correlated to the degree of lipoprotein aggregation. When aggregates were removed from the lipoprotein preparations by filtration, the latter became less effective in promoting intracellular lipid accumulation. Incubation of cells with lipoprotein aggregates, isolated by gel filtration, induced a 3- to 5-fold elevation of the cellular cholesteryl ester content.
\end{abstract}

These results suggest that LDL from artherosclerotic patients, or LDL from diabetic patients, or Lp(a) have a tendency to form aggregates and that these aggregates are avidly taken up by intimal smooth muscle cells followed by lipid accumulation. This aggregation tendency may play a role in atherogenesis.

\section{Introduction}

The accumulation of cholesteryl esters in intimal smooth muscle cells is one of the earliest manifestations of atherosclerosis. Despite intensive investigative work, the molecular mechanisms underlying lipid deposition within the cells still remain unknown. Native LDL properly isolated from healthy subjects fails to induce intracellular lipid accumulation in cultured cells $(1-3)$, while incubation of cells with LDL chemically modified by acetylation, methylation, glycation, oxidation, desialylation, or by malondialdehyde, glutaraldehyde or 4-hydroxynonenal treatment results in deposition of lipid within the cells $(1,3$, $4-10)$. We recently reported that LDL after modifi- cations in vitro form aggregates under cell culture conditions (11). The degree of aggregation of modified LDL is correlated with their ability to increase the intracellular cholesterol ester content. Removal of these aggregates from preparations of modified LDL resulted in a marked suppression of lipid accumulation in cultured cells. These findings demonstrate that the ability of in vitro modified LDL to promote intracellular lipid deposition depends largely on its aggregation. Several types of modified LDL have been shown to occur in human blood. Thus Curtiss \& Witztum (12) demonstrated the presence of glycated LDL in the circulation of hyperglycaemic diabetic patients, and recently it was shown that LDL 
from atherosclerotic patients differs from LDL from healthy donors by a lower content of sialic acid (8, 9). This desialylated lipoprotein species induces intracellular lipid accumulation in cultured aortic cells (13, 14). Another circulating lipoprotein, which has been implicated in the deposition of lipids into cells (15$18)$ is lipoprotein(a) $(\mathrm{Lp}(\mathrm{a}))$. This lipoprotein is similar to LDL but in addition to apolipoprotein B-100, it also contains the $\mathrm{Lp}(\mathrm{a})$ glycoprotein, apolipoprotein (a). The molecular mass of apolipoprotein(a) ranges from 350000 to 900000 depending on the genetic isoform (19). In many epidemiological studies a positive correlation of high serum $\mathrm{Lp}(\mathrm{a})$ concentrations with coronary heart disease has been demonstrated $(20-22)$.

The present work was undertaken to study whether

1) LDL isolated from subjects suffering from coronary heart disease or diabetes show an increased tendency to form aggregates under cell culture conditions,

2) whether LDL aggregates or Lp(a) aggregates cause accumulation of cholesteryl esters into aortic intimal cells in culture, and

3) whether removal of these aggregates results in a decrease in intimal cholesteryl ester accumulation.

\section{Materials and Methods}

\section{Preparation of lipoproteins}

Low density lipoprotein $(\mathrm{d}=1.019-1.055 \mathrm{~kg} / \mathrm{l})$ was isolated by sequential ultracentrifugation (23) from:

1) combined plasma from 12 healthy subjects,

2) from 12 patients with coronary heart disease (angiographically documented stenosis of coronary arteries), and

3) from 12 non-insulin-dependent diabetic patients.

The clinical characteristics of the coronary heart disease patients and the healthy donors have been described $(13,14,24)$. None of the coronary heart disease patients or the healthy donors had diabetes mellitus. In the three groups the mean cholesterol concentrations were essentially similar, i.e. $5.12 \pm 0.33,5.04$ \pm 0.26 and $4.76 \pm 0.13 \mathrm{mmol} / \mathrm{l}$ for coronary heart disease patients, diabetic patients and healthy subjects, respectively. HDL-cholesterol concentrations in respective groups were 0.96 $\pm 0.10,1.01 \pm 0.08$ and $1.14 \pm 0.16 \mathrm{mmol} / \mathrm{l}$. Plasma apolipoprotein B concentrations were $0.99 \pm 0.07,0.98 \pm 0.09$ and $0.88 \pm 0.06 \mathrm{~g} / \mathrm{l}$, respectively for coronary heart disease and diabetic patients and for healthy subjects.

To prevent lipoprotein oxidation and proteolysis, butylated hydroxytoluene (final concentration $2 \mu \mathrm{mol} / \mathrm{l}$ ) and phenylmethylsulphonyl fluoride (final concentration $1 \mathrm{mmol} / \mathrm{l}$ ) were added. After recentrifugation at $d=1.055 \mathrm{~kg} / \mathrm{l}$, the LDL preparations were dialysed against phosphate-buffered saline, filtered through a $0.22 \mu \mathrm{m}$ polycarbonate filter and stored for a maximum of 7 days at $+4^{\circ} \mathrm{C}$. Immediately before use, the preparations were refilteted. The main characteristics of the LDL preparations obtained are summarized in table 1 . The sialic acid content was determined by the method of Warren (25). The extent of LDL glycation was evaluated from the fructosyl-lysine content, as determined by the method of KruseJarres et al. (26) using Boehringer Mannheim kits (Mannheim, Germany). The level of thiobarbituric acid reactive products in LDL and Lp(a) preparations was determined according to Yagi (27).

Lipoprotein(a) was isolated by sequential ultracentrifugation, gel filtration on Sepharose 4B, and chromatography on Heparin Sepharose, as described previously $(28,29)$.

Determination of the degree of lipoprotein aggregation and the size of aggregates

The degree of lipoprotein aggregation was evaluated by methods based on analysis of light transmission fluctuations in LDL and $L p(a)$ suspensions (30). The aggregate size was determined by quasi-elastic laser scattering on an Autosizer 2 (Malvern Instrument, U. K.).

\section{Cell culture}

Subendothelial cells were isolated from grossly normal intima by dispersion of human aortic tissue with $1.5 \mathrm{~g} / \mathrm{l}$ collagenase, and cultured in growth medium containing Medium 199, fetal calf serum, volume fraction $0.1,2 \mathrm{mmol} / \mathrm{l} L$-glutamine, and antibiotics (GIBCO Europe, Paisley) as described previously (31). The cells were cultured at $37^{\circ} \mathrm{C}$ in a humidified $\mathrm{CO}_{2}$ incubator $\left(0.95 \mathrm{air} / 0.05 \mathrm{CO}_{2}\right)$. The medium was changed every day. Starting from the 7 th day in primary culture, cells were incubated for $6 \mathrm{~h}$ in medium containing LDL from healthy donors, or LDL from coronary heart disease patients or diabetic patients (protein $100 \mathrm{mg} / \mathrm{l}$ ) and lipoprotein-deficient serum, volume fraction 0.1 (prepared by ultracentrifugation (23) from a healthy donor $(\mathrm{d}>1.250 \mathrm{~kg} / \mathrm{l}))$. Medium and lipoprotein preparations were filtered $(0.22 \mu \mathrm{m}$ pore size $) \mathrm{im}$ mediately before adding to cell cultures. Human peripheral blood monocytes were isolated and incubated with lipoprotein preparations as described previously (24). After incubation the cells were rinsed and cellular lipids determined, as described below.

\section{Analytical methods}

Protein was determined by the method of Lowry et al. (32) Intracellular lipids were extracted with a $n$-hexane-isopropanol mixture $(3+2$, by vol.) as described elsewhere (33). To determine the cholesterol ester content, the amount of free and total cholesterol was measured by the method of Siedel (34) using Boehringer Mannheim reagents (Mannheim, Germany). Lipids were extracted from lipoproteins with a chloroform-methanol mixture $(2+1$, by vol.) according to Bligh \& Dyer (35). Phospholipids and neutral lipids were separated by thin-layer chromatography and measured by scanning densitometry (31). Lipoprotein(a) was quantitated with an immunoradiometric (IRMA)-method as described previously (36).

\section{Statistical analysis}

The significance of differences between groups was evaluated by multiple t-test of one-way analysis of variance using a BMDP statistical program package (37). The Bonferoni method was used to compare the study groups with the control group (38).

\section{Results}

Characterization of lipoprotein preparations

Table 1 shows some characteristics of the lipoprotein preparations examined in the present study. The protein and lipid composition of LDL obtained from 
Tab. 1. Characteristics of lipoprotein preparations.

\begin{tabular}{|c|c|c|c|c|c|c|c|c|}
\hline \multirow{2}{*}{$\begin{array}{l}\text { Lipo- } \\
\text { protein }\end{array}$} & \multicolumn{5}{|c|}{ Composition (\%) } & \multirow{2}{*}{$\begin{array}{l}\text { Thiobarbi- } \\
\text { turic acid } \\
\text { reactive } \\
\text { substance } \\
\text { ( } \mu \text { mol/g } \\
\text { apolipo- } \\
\text { protein } B \text { ) }\end{array}$} & \multirow{2}{*}{$\begin{array}{l}\text { Sialic acid } \\
\text { content } \\
(\mu \mathrm{mol} / \mathrm{g} \\
\text { apolipo- } \\
\text { protein } \mathrm{B})\end{array}$} & \multirow{2}{*}{$\begin{array}{l}\text { Fructosyl- } \\
\text { lysine } \\
\text { content } \\
\text { ( } \mu \mathrm{mol} / \mathrm{g} \\
\text { apolipo- } \\
\text { protein B) }\end{array}$} \\
\hline & Protein & $\begin{array}{l}\text { Phospho- } \\
\text { lipids }\end{array}$ & $\begin{array}{l}\text { Free } \\
\text { cholesterol }\end{array}$ & $\begin{array}{l}\text { Triacyl- } \\
\text { glycerols }\end{array}$ & $\begin{array}{l}\text { Cholesteryl } \\
\text { esters }\end{array}$ & & & \\
\hline & & & & & & \multicolumn{3}{|c|}{ Healthy subjects } \\
\hline LDL & 20.5 & 23.1 & 12.5 & 5.5 & 38.3 & 1.1 & 30.8 & 23.9 \\
\hline \multirow[t]{2}{*}{ LDL } & 22.0 & 22.8 & 12.2 & 6.0 & 37.0 & \multicolumn{3}{|c|}{ CHD patients } \\
\hline & & & & & & \multicolumn{3}{|c|}{ Diabetic patients } \\
\hline LDL & 21.5 & 21.6 & 12.2 & 6.2 & 38.5 & 1.2 & 15.8 & 31.9 \\
\hline $\mathrm{Lp}(\mathrm{a})$ & 28.3 & 20.5 & 10.7 & 4.2 & 36.3 & 1.4 & 130.0 & - \\
\hline
\end{tabular}

healthy subjects and atherosclerotic or diabetic patients are essentially similar. There was no significant difference in the content of thiobarbituric acid reactive substance between LDL preparations obtained from healthy subjects and patients. The sialic acid content in LDL of coronary heart disease patients was 3-fold lower than that measured in LDL of healthy subjects. In LDL of diabetic patients a high content of fructosyl-lysine was present due to enhanced glycation (tab. 1).

In $L p(a)$ isolated from coronary heart disease subjects the ratios between the major lipid classes were similar to those in LDL from healthy donors. The sialic acid content of $\mathrm{Lp}$ (a) was approximately 13-fold higher than that of LDL, while the thiobarbituric acid reactive substance content did not differ significantly from that of LDL.

\section{Effect of lipoproteins on intracellular lipid accumulation}

When intimal cells (cultured from grossly normal human aorta) were incubated in the presence of the different lipoprotein preparations, they accumulated varying quantities of cholesteryl esters (tab. 2).

After $6 \mathrm{~h}$ of incubation, LDL from healthy donors induced no significant increase in the intracellular cholesterol ester content. In contrast, LDL isolated from coronary heart disease patients significantly increased the cholesteryl ester content of the cultured cells (tab. 2). The intracellular cholesteryl ester content also increased after the cells had been incubated with LDL preparations from diabetic patients. This 6-h incubation of intimal cells with patient-LDL or LDL of healthy donors produced no significant increase in the intracellular content of free cholesterol (data not shown).
Tab. 2. Effect of LDL from healthy donors, coronary heart disease patients and diabetic patients on cholesteryl ester accumulation in aortic intimal cells and human monocytes.

\begin{tabular}{llc}
\hline & $\begin{array}{l}\text { Cholesteryl ester content } \\
\text { (mg/g protein) }\end{array}$ \\
\hline & $\begin{array}{l}\text { Intimal smooth } \\
\text { muscle cells }\end{array}$ & Monocytes \\
& $19 \pm 1$ & $6 \pm 1$ \\
\hline Control & $20 \pm 2$ & $9 \pm 1$ \\
LDL of healthy subjects & $82 \pm 7^{*}$ & $22 \pm 2^{*}$ \\
LDL of coronary heart & $96 \pm 6^{*}$ & $28 \pm 2^{*}$ \\
disease patients & $66 \pm 4^{*}$ & $15 \pm 1^{*}$ \\
Lipoprotein (a) & & \\
\hline
\end{tabular}

Aortic intimal cells or monocytes were incubated for $6 \mathrm{~h}$ in Medium 199 containing lipoprotein-deficient serum, volume fraction 0.1 and freshly filtered $(0.22 \mu \mathrm{m}$ pore diameter $)$ lipoprotein preparations (protein concentration 100 and $50 \mathrm{mg} / \mathrm{l}$, respectively). Control cells were incubated in Medium 199 containing lipoprotein deficient serum, volume fraction 0.1 . The data are the mean of 4 determinations \pm SEM.

* significant difference from the control, $\mathrm{p}<0.05$.

Lipoprotein(a), at a concentration of $100 \mathrm{mg} / \mathrm{l}$, induced a 3-fold increase in esterified cholesterol, but not in the free cholesterol content of the cells (tab. 2), compared with the concentration observed after incubation of the cells with LDL from healthy donors.

We also examined the effects of LDL and $L p(a)$ on the cholesteryl ester content of human peripheral blood monocytes. At a concentration of $50 \mathrm{mg} / \mathrm{l}, \mathrm{LDL}$ isolated from coronary heart disease patients or diabetic patients, as well as $L p(a)$ promoted a 2 to 3fold rise in intracellular cholesteryl ester in cultured monocytes (tab. 2), compared with that observed after incubation with LDL from healthy donors. 
Lipoprotein aggregation under cell culture conditions

Table 3 illustrates alterations in average particle size for lipoprotein preparations incubated with cultured cells at $37^{\circ} \mathrm{C}$ in medium 199 containing lipoproteindeficient serum, volume fraction 0.05 . LDL isolated from healthy donors demonstrated no appreciable change in average particle size for up to $24 \mathrm{~h}$ of incubation. In contrast, when LDL from atherosclerotic patients, or LDL from diabetic patients, or $\mathrm{Lp}(\mathrm{a})$ were incubated in the presence of cells, a significant increase in the average particle size of LDL and Lp(a) was observed within 6 hours of incubation (tab. 3).

Tab. 3. Alterations in the average size of lipoprotein particles during incubation under the conditions of cell culture.

\begin{tabular}{llrr}
\hline & \multicolumn{3}{l}{$\begin{array}{l}\text { Average particle size } \\
\text { (rel. units) }\end{array}$} \\
\cline { 2 - 4 } & \multicolumn{4}{l}{ Time of incubation (h) } \\
& 0 & 6 & 24 \\
\hline LDL of healthy subjects & 5.4 & 5.6 & 5.9 \\
Coronary heart disease patients' LDL & 5.8 & 12.9 & 23.4 \\
Diabetic patients' LDL & 6.1 & 15.7 & 27.8 \\
Lipoprotein (a) & 7.8 & 10.4 & 20.7 \\
\hline
\end{tabular}

Freshly filtered $(0.22 \mu \mathrm{m})$ preparations of LDL of healthy subjects, coronary heart disease and diabetic patients, or lipoprotein (a) were incubated in Medium 199 containing lipoprotein-deficient serum, volume fraction 0.05 with smooth muscle cells from grossly normal human aortic intima for the indicated time period. Lipoprotein average size was determined by laser correlative photometry.

A direct and strong correlation $(\mathrm{r}=0.88, \mathrm{n}=28$, $\mathrm{p}<0.01)$ was established between the degree of lipoprotein aggregation and cholesteryl ester accumulation in cultured intimal cells. The diameters of glycated, desialylated LDL and lipoprotein(a) aggregates were $70-200,100-500$ and $200-400 \mathrm{~nm}$, respectively, as determined by laser spectroscopy. The average diameters of LDL and lipoprotein(a) particles from healthy subjects were $27 \mathrm{~nm}$ and $35 \mathrm{~nm}$, respectively.

\section{Effect of aggregate removal from lipoprotein preparations}

To study the role of lipoprotein aggregates on lipid accumulation in cultured cells, we removed aggregated lipoproteins from LDL preparations by filtration. For this purpose filtered LDL preparations that had been incubated for $6 \mathrm{~h}$ at $37^{\circ} \mathrm{C}$ with cells were again passed through polycarbonate filters to remove aggregates. The filtered LDL was then incubated with cultured intimal cells under the same conditions as previously. Subsequently, LDL aggregation and intracellular cholesteryl ester content were analysed. After filtration, the average diameters of aggregates in filtered preparations of LDL from coronary heart disease patients were significantly reduced, compared with those in the initial preparations (tab. 4). When cells were incubated with these refiltered preparations, a much lower cholesteryl ester accumulation was observed, and when the LDL-preparations were passed through $0.1 \mu \mathrm{m}$ filters they completely lost their ability to induce intracellular lipid accumulation.

Lipoprotein aggregates were also removed by gel filtration. After passage through a Sepharose CL-2B column, isolated preparations of $\mathrm{Lp}(\mathrm{a})$, or patientLDL, which initially caused intracellular lipid deposition in intimal cells, lost their ability to increase lipid accumulation (tab. 5).

As shown in table 5, aggregates of LDL from atherosclerotic or diabetic patients, as well as Lp(a) aggre-

Tab. 4. Effect of lipoprotein filtration on their ability to induce the accumulation of cholesteryl esters in the smooth muscle cells of unaffected human aortic intima and human blood monocytes.

Pore size $(\mu \mathrm{m}) \quad$ Average size (arb. units)
Cholesteryl ester content

(mg/g protein)

\begin{tabular}{cc}
\hline $\begin{array}{l}\text { Intimal smooth } \\
\text { muscle cells }\end{array}$ & Monocytes \\
$43 \pm 2$ & $8 \pm 1$ \\
$123 \pm 12^{*}$ & $17 \pm 2^{*}$ \\
$105 \pm 10^{*}$ & $13 \pm 2^{*}$ \\
$75 \pm 5^{*}$ & $9 \pm 1$ \\
$52 \pm 6$ & $9 \pm 1$
\end{tabular}
$17 \pm 2 *$
$9 \pm 1$

LDL of healthy subjects

Coronary heart disease patients' LDL

$\begin{array}{rr} & 6.0 \\ & 27.7 \\ 0.45 & 19.7 \\ 0.22 & 12.6 \\ 0.10 & 7.9\end{array}$

LDL preparations were filtered through $0.22 \mu \mathrm{m}$ filters and preincubated for $6 \mathrm{~h}$ in Medium 199 containing lipoprotein-deficient serum, volume fraction 0.05 . After preincubation, LDL preparations were carefully filtered through $0.1 \mu \mathrm{m}, 0.22 \mu \mathrm{m}$ and $0.45 \mu \mathrm{m}$ filters and added to cells at an apolipoprotein B concentration of $0.1 \mathrm{~g} / 1$. Following $6 \mathrm{~h}$ of incubation, cells were rinset and their cholesteryl ester content was measured. Values listed are means of 4 determinations \pm SEM.

* significant difference from the control, $\mathrm{p}<0.01$. 
Tab. 5. Effects of aggregated and non-aggregated LDL on the cholesteryl ester content in cultured smooth muscle cells.

\begin{tabular}{lccc}
\hline & \multicolumn{2}{l}{$\begin{array}{l}\text { Cholesteryl ester accumulation } \\
\text { (\% above control) }\end{array}$} \\
\cline { 2 - 4 } & $\begin{array}{l}\text { Total } \\
\text { lipoprotein }\end{array}$ & $\begin{array}{l}\text { Non-aggre- } \\
\text { gated } \\
\text { lipoprotein }\end{array}$ & $\begin{array}{l}\text { Aggregated } \\
\text { lipoprotein }\end{array}$ \\
\hline $\begin{array}{l}\text { Native LDL of } \\
\text { healthy subjects }\end{array}$ & $7 \pm 12$ & $4 \pm 7$ & - \\
$\begin{array}{l}\text { Coronary heart } \\
\text { disease patients' } \\
\text { LDL }\end{array}$ & $103 \pm 7^{*}$ & $17 \pm 11$ & $311 \pm 19^{*}$ \\
$\begin{array}{l}\text { Diabetic patients' } \\
\text { LDL }\end{array}$ & $187 \pm 20^{*}$ & $5 \pm 8$ & $323 \pm 14^{*}$ \\
$\begin{array}{l}\text { Lipoprotein (a) } \\
\text { Lipo }\end{array}$ & $79 \pm 9^{*}$ & $8 \pm 10$ & $395 \pm 13^{*}$ \\
\hline
\end{tabular}

Freshly filtered lipoprotein preparations were preincubated for $6 \mathrm{~h}$ at $37^{\circ} \mathrm{C}$. Aggregated and non-aggregated modified lipoprotein were separated by gel filtration on a Sepharose CL-2B column $(1.6 \times 90 \mathrm{~cm})$ at a flow rate of $1.5 \mathrm{ml} / \mathrm{min}$. Fractions of aggregated and non-aggregated lipoproteins were pooled and examined for their ability to induce cholesteryl ester accumulation in cultured smooth muscle cells from grossly normal human aortic intima. The data are the means of 4 determinations \pm SEM.

* significant difference from control, $\mathrm{p}<0.05$. Control cells were incubated in Medium 199 with lipoprotein-deficient serum, volume fraction 0.1 . Cholesteryl ester concentration in control smooth muscle cells was $29 \pm 3 \mathrm{mg} / \mathrm{g}$ protein.

gates, induced a 4-5-fold increase in intracellular cholesterol ester content. Similar results were obtained for cultured human peripheral blood monocytes (tab. 6). To find out whether the uptake of LDL aggregates was mediated by phagocytosis, we examined the influence of the phagocytosis inhibitor, cytochalasin B, on the cholesteryl ester accumulation in cultured cells caused by aggregates. This agent inhibited the increase of cholesteryl ester level both in smooth muscle cells and in monocytes (tab. 7).
Tab. 6. Effect of aggregated lipoprotein on the cholesteryl ester content of cultured human peripheral blood monocytes.

\begin{tabular}{ll}
\hline Source of aggregates & $\begin{array}{l}\text { Cholesteryl ester accumulation } \\
\text { (\% above control) }\end{array}$ \\
\hline $\begin{array}{l}\text { Coronary heart disease } \\
\text { patients' LDL }\end{array}$ & $307 \pm 18^{*}$ \\
$\begin{array}{l}\text { Diabetic patients } \\
\text { LDL }\end{array}$ & $389 \pm 45^{*}$ \\
Lipoprotein (a) & $322 \pm 33^{*}$ \\
\hline
\end{tabular}

Human peripheral blood monocytes were incubated for $6 \mathrm{~h}$ in Medium 199 containing lipoprotein deficient serum, volume fraction 0.1 and $50 \mathrm{mg} / \mathrm{l}$ of aggregated lipoproteins. Aggregated lipoproteins were obtained as indicated in the legend to table 5. Control cells were incubated in the absence of lipoprotein aggregates. The data are the means of 4 determinations \pm SEM

* significant difference from control, $\mathrm{p}<0.05$. Control cells were incubated in Medium 199 with lipoprotein deficient serum, volume fraction 0.1 . The amount of cholesteryl ester in control monocytes was $6 \pm 1 \mathrm{mg} / \mathrm{g}$ protein.

\section{Discussion}

The present study demonstrates the LDL isolated from patients with coronary heart disease or diabetes, as well as lipoprotein(a), induce accumulation of cholesteryl esters in cultured human aortic intimal cells and in peripheral blood monocytes. This is in contrast to LDL isolated from healthy subjects using the same techniques. We have previously shown that in vitro modified LDL undergoes aggregation, and that this aggregation of the modified LDL plays a crucial role in intracellular lipid accumulation (11).

It was therefore of interest to study whether LDL isolated from patients might in vivo have been modified in such a way that they display a tendency to aggregate.

Here we provide evidence that LDL isolated from patients with coronary heart disease or diabetes mel-

Tab. 7. Effects of cytochalasin B on cholesteryl ester accumulation in intimal smooth muscle cells and human monocytes.

\begin{tabular}{|c|c|c|c|c|}
\hline & \multicolumn{4}{|c|}{ Cholesteryl ester content, $\mathrm{mg} / \mathrm{g}$ protein } \\
\hline & \multirow{2}{*}{\multicolumn{2}{|c|}{$\frac{\text { Intimal smooth muscle cells }}{\text { Cytochalasin } \mathrm{B}, 10 \mathrm{mg} / \mathrm{l}}$}} & \multicolumn{2}{|c|}{ Monocytes } \\
\hline & & & & \\
\hline & - & + & - & + \\
\hline Control & \multicolumn{2}{|l|}{$21 \pm 1$} & \multicolumn{2}{|l|}{$6 \pm 1$} \\
\hline Aggregates of LDL from coronary heart disease patients & $60 \pm 3$ & $27 \pm 3^{*}$ & $25 \pm 2$ & $7 \pm 1^{*}$ \\
\hline Aggregates of LDL from diabetic patients & $56 \pm 5$ & $28 \pm 2 *$ & $26 \pm 2$ & $8 \pm 1^{*}$ \\
\hline Aggregates of lipoprotein (a) & $68 \pm 7$ & $24 \pm 2 *$ & $26 \pm 3$ & $8 \pm 1^{*}$ \\
\hline
\end{tabular}

Details of the experiments are the same as described in tables 5 and 6.

* significant difference from samples without cytochalasin $\mathrm{B}, \mathrm{p}<0.05$. 
litus show an increased tendency to form aggregates. In contrast, LDL from healthy donors do not aggregate to a measurable degree under the experimental conditions used in this study. Thus, some kind of lipoprotein modification appears to take place in vivo under pathological conditions such as atherosclerosis and diabetes. The mechanisms underlying the increased tendency for lipoprotein aggregation is at present unclear. The changes in the lipid or protein moieties leading to increased aggregation may include a wide range of chemical modifications.

Fogelman et al. (5) were the first to demonstrate that LDL cross-linked by glutaraldehyde induced cholesteryl ester accumulation in human monocyte-macrophages. Recently, Hoff et al. reported that 4-hydroxynonenal, produced upon lipid peroxidation, is capable of causing cross-linking of lipoproteins (39) and that the lipoprotein aggregates thus formed elevate the intracellular cholesteryl ester concentration in cultured macrophages. Khoo et al. reported that aggregates prepared by vortexing LDL suspension promote lipid accumulation in macrophages, but not in smooth muscle cells (40). Our earlier findings show (11) that in vitro modified LDL spontaneously aggregate under the conditions of cell culture and that his aggregation is a necessary step in the process of cholesteryl ester accumulation within cultured human aortic smooth muscle cells. The present study indicates that, under these conditions, in vivo modified LDL also undergoes aggregation, and is able to increase the cholesteryl ester content of cultured aortic smooth muscle cells. In addition, cytochalasin $\mathrm{B}$, an inhibitor of cellular

\section{References}

1. Traber, M. G. \& Kayden, H. J. (1980) Low density lipoprotein receptor activity in human monocyte derived macrophages and its relation to atheromatous lesions. Proc. Natl. Acad. Sci. USA 77, 5466-5470.

2. Schechter, I., Fogelman, A. M., Haberland, M. E., Seager, J., Hokom, M. \& Edwards, P. A. (1981) The metabolism of native and malondialdehyde-altered low density lipoproteins by human monocyte-macrophages. J. Lipid. Res. 22, $63-71$

3. Leak, D. S. \& Peters, T. J. (1982) Lipid accumulation in arterial smooth muscle cells in culture. Morphological and biochemical changes caused by low density lipoproteins and chloroquine. Atherosclerosis 44, 275-291.

4. Mahley, R. W., Innerarity, T. L. Weisgraber, K. H. \& Oh, S. Y. (1979) Altered metabolism (in vivo and in vitro) of plasma lipoproteins after selective chemical modification of lysine residues of the apoproteins. J. Clin. Invest. 64, 743750.

5. Fogelman, A. M., Schechter, I., Seager, J., Hokom, M., Child, J. S. \& Edwards, P. A. (1980) Malondialdehyde alteration of low density lipoprotein leads to cholesteryl ester accumulation in human monocyte-macrophages. Proc. Natl. Acad. Sci. USA 77, 2214-2218. phagocytosis, decreased the uptake and degradation of LDL aggregates. These findings strongly suggest that phagocytosis is the mechanism responsible for the uptake of LDL aggregates.

In earlier work it was demonstrated that oxidized and malondialdehyde-treated LDL show an increased tendency for aggregation (11). Jürgens demonstrated that lysophosphatidylcholine can provoke aggregation of $L p(a)$ (41). On the other hand, we have found that modified LDL and $\mathrm{Lp}(\mathrm{a})$ bind to native LDL (Tertov et al., unpublished data), an observation consistent with the findings of $Y e$ et al. (42). These data suggest that the aggregates may consist of both modified and native LDL.

In addition to LDL aggregates, "associates" between lipoproteins and various connective tissue components, such as proteoglycans $(43,44)$, collagenaseresistent debris (45), heparin-fibronectin-denaturated collagen (46), fibronectin (47), and elastin (48) have been described. All these "associates" seem to be able to induce lipid accumulation in macrophages and smooth muscle cells. Recently, an association of LDL with mast cells and subsequent proteolytic modification of LDL were described, and it was shown that these mast cell-modified LDL are able to increase the cholesterol ester content of macrophages (49-51). LDL-antibody complexes elicit the same effect (52). Taken together, these data suggest that the formation of lipoprotein-aggregates favour the accumulation of cholesterol esters in human aortic intimal cells, and may play an important role in atherogenesis.
6. Witztum J. L, Mahoney, E. M., Branks, M. J., Fisher, M Elam, R. \& Steinberg, D. (1982) Nonenzymatic glycosylation of low density lipoprotein alters its biologic activity. Diabetes 31, 283-291.

7. Steinbrecher, U. P., Parthasarathy, S., Leak, D. S., Witztum, J. L. \& Steinberg, D. (1984) Modification of low density lipoprotein by endothelial cells involves lipid peroxidation and degradation of low density lipoprotein phospholipids. Proc. Natl. Acad. Sci. USA 81, 3883-3887.

8. Orekhov, A. N., Tertov, V. V., Mukhin, D. N. \& Mikhailenko, I. A. (1989) Modification of low density lipoprotein by desialylation causes lipid accumulation in cultured cells Discovery of desialylated lipoprotein with altered cellular metabolism in the blood of atherosclerotic patients Biochem. Biophys. Res. Commun. 162, 206-211

9. Orekhov, A. N., Tertov, V. V., Mukhin, D. N. \& Kabakov, A. E. (1989) Modified (desialylated) low density lipoprotein and autoantibodies against lipoprotein circulating in the blood of atherosclerotic patients cause atherosclerotic manifestation in aortic cell culture. In: Atherosclerosis and Cardiovascular Disease (Descovich, G. C., ed.) Bologna, Editrice Compositori, vol. 4. pp. 523-529. 
10. Jürgens, G., Lang, J. \& Esterbauer, H. (1986) Modification of human low-density lipoprotein by the lipid peroxidation product 4-hydroxynonenal. Biochim. Biophys. Acta 875, $103-114$.

11. Tertov, V. V., Sobenin, I. A., Gabbasov, Z. A., Popov, E. G. \& Orekhov, A. N. (1989) Lipoprotein aggregation as an essential condition of intracellular lipid accumulation caused by modified low density lipoproteins. Biochem. Biophys. Res. Commun. 163, 489-494.

12. Curtiss, L. K. \& Witztum, J. L. (1985) Plasma lipoproteins $\mathrm{AI}, \mathrm{AII}, \mathrm{B}, \mathrm{CI}$ and $\mathrm{E}$ are glycosylated in hyperglycemic diabetic subjects. Diabetes $34,452-461$

13. Orekhov, A. N., Tertov, V. V., Pokrovsky, S. N., Adamova, I. Y., Martsenyuk, O. N. \& Lyakishev, A. A., Smirnov, V. N. (1988) Blood serum atherogenicity associated with coronary atherosclerosis. Evidence for non-lipid factor providing atherogenicity of low-density lipo-proteins and an approach to its elimination. Circ. Res. 62, 421-429.

14. Tertov, V. V., Orekhov, A. N., Martsenyuk, O. N., Perova, N. V. \& Smirnov, V. N. (1989) Low-density lipoproteins isolated from the blood of patients with coronary heart disease induce the accumulation of lipids in human aortic cells. Exp. Mol. Pathol. 50, 337-347.

15. Walton, K. W., Hitchens, J., Magnani, H. N. \& Khan, M. (1974) A study of methods of identification and estimation of $\mathrm{Lp}(\mathrm{a})$ lipoprotein and its significance in health, hyperlipidaemia and atherosclerosis. Atherosclerosis 20, 323346.

16. Cushing, G. L., Gaubatz, J. W., Nava, M. L., Burdick, B. J., Bocan, T. M. A., Guyton, J. R., Weilbaecher, D., DeBakey, M. E., Lawrie, G. M. \& Morrisett, J. D. (1989) Quantitation and localization of apolipoproteins (a) and B in coronary artery bypass vein grafts resected at re-operation. Arteriosclerosis 9, 513-603.

17. Rath, M., Niendorf, A., Reblin, T., Dietel, M., Krebber, H.-J. \& Beisiegel, U. (1989) Detection and quantification of lipoprotein (a) in the arterial wall of 107 coronary bypass patients. Arteriosclerosis 9, 579-592.

18. Smith, E. B. \& Cochran, S. (1990) Factors influencing the accumulation in fibrous plaques of lipid derived from low density lipoprotein. II. Preferential immobilization of lipoprotein (a) [Lp(a)]. Atherosclerosis 84, 173-181.

19. Utermann, G., Menzel, H. J., Kraft, H. G., Duba, H. C., Kemmler, H. G. \& Seitz, C. (1987) Lp(a) glycoprotein phenotypes. Inheritance and relation to $\mathrm{Lp}(\mathrm{a})$ lipoprotein concentrations in plasma. J. Clin. Invest. 80, 458-465.

20. Schriewer, H., Assmann, G. \& Sandkamp, M. (1984) The relationship of lipoprotein (a), $\mathrm{Lp}$ (a) to risk factors of coronary heart disease. J. Clin. Chem. Clin. Biochem. 22, $591-596$.

21. Dahlen, G., Guyton, J. R., Attar, M., Farner, J. A., Kautz, J. A. \& Gotto, A. M. (1986) Association of levels of lipoprotein (a), plasma lipids, and other lipoproteins with coronary artery disease documented by angiography. Circulation $74,758-765$

22. Rhoads, G. G., Dahlen, G., Berg, K., Morton, N. E. \& Dannenberg, A. L. (1986) Lp(a) lipoprotein as a risk factor for myocardial infarction. J. Am. Med. Ass. 256, $2540-$ 2544.

23. Havel, R. J., Eder, H. A. \& Bragdon, J. H. (1955) The distribution and chemical composition of ultracentrifugally separated lipoprotein in human serum. J. Clin. Invest. 34, $1345-1353$.

24. Chazov, E. I., Tertov, V. V., Orekhov, A. N., Lyakishev, A. A., Perova, N. V., Kurdanov, Kh. A., Khashimov, Kh. A., Novikov, I. D. \& Smirnov, V. N. (1986) Atherogenicity of blood serum from patients with coronary heart disease. Lancet 2, 595-598.

25. Warren, L. (1959) The thiobarbituric acid assay of sialic acids. J. Biol. Chem. 234, 1971-1975.

26. Kruse-Jarres, J. D., Jarausch, J., Lehmann, P., Vogt, B. W. \& Rietz, P. (1989) A new calorimetric method for the determination of fructosamine. Lab. Med. 13, 245-253.
27. Yagi, K. (1984) Lipid peroxidation. Assay for blood plasma and serum. Methods Enzymol. 105, 328-333.

28. Ehnholm, C., Garoff, H., Simons, K. \& Aro, H. (1971) Purification and quantitation of the human plasma lipoprotein carrying the $\mathrm{Lp}(\mathrm{a})$ antigen. Biochim. Biophys. Acta $236,431-439$

29. Jauhiainen, M., Metso, J., Koskinen, P. \& Ehnholm, C. (1991) Characterization of the enzyme activity of human plasma lipoprotein (a) using synthetic peptide substrates. Biochem. J. 274, $491-496$.

30. Gabbasov, Z. A., Popov, E. G., Gavrilov, I. Yu. \& Pozin, E. Y. (1989) Platelet aggregation: the use of optical density fluctuations to study microaggregate formation in platelet suspension. Thrombosis Res. 54, 215-223.

31. Orekhov, A. N., Tertov, V. V., Novikov, I. D., Krushinsky, A. V., Andreeva, E. R., Lankin, V. Z. \& Smirnov, V. N. (1985) Lipids in cells of atherosclerotic and uninvolved human aorta. I. Lipid composition of aortic tissue and enzyme isolated and cultured cells. Exp. Mol. Pathol. 42, $117-137$.

32. Lowry, O. H., Rosebrough, N. J., Farr, A. L. \& Randall, R. J. (1951) Protein measurement with the Folin phenol reagent. J. Biol. Chem. 193, 265-275

33. Hara, A. \& Radin, N. S. (1978) Lipid extraction of tissue with a low-toxicity solvent. Anal. Biochem. 90, 420-426.

34. Siedel, J., Hagele, E. O., Ziegenhorn, J. \& Wahlefeld, A. W. (1983) Reagent for enzymatic determination of serum total cholesterol with improved lipolytic efficiency. Clin. Chem. 29, 1075-1080.

35. Bligh, E. G. \& Dyer, W. J. (1959) A rapid method of total lipid extraction and purification. Can. J. Biochem. Physiol. 37, $911-917$.

36. Jauhiainen, M., Ehnholm, C., Huttunen, J. K., Koskinen, P., Frick, M. H., Mänttäri, M. \& Manninen, V. (1991) Lipoprotein (a) and coronary heart disease risk: A nested case-control study of the Helsinki Heart Study participants. Atherosclerosis 89, 59-67.

37. Dixon, W. J. \& Brown, M. B. (1977) Biomedical Computer Programs. P-Series. Berkley, University of California Press, pp. $185-198$.

38. Wallenstein, S., Zucker, C. L. \& Fleiss, J. L. (1980) Some statistical methods useful in circulation research. Circ. Res. $47,1-49$.

39. Hoff, H. F., O'Neil, J., Chisolm, G. M. III, Cole, T. B. Quehenberger, O., Esterbauer, H. \& Jürgens, G. (1989) Modification of low density lipoprotein with 4-hydroxynonenal induces uptake by macrophages. Arteriosclerosis 9, 538-549.

40. Khoo, J. C., Miller, E., McLoughlin, P. \& Steinberg, D. (1988) Enhanced macrophage uptake of low density lipoprotein after self-aggregation. Arteriosclerosis $8,348-358$.

41. Jürgens, G. (1983) In vitro studies on the aggregation of isolated lipoprotein (a) upon addition of lysolecithin. Artery $11,243-249$.

42. Ye, S. Q., Trieu, V. N., Stiers, D. L. \& McConathy, W. J. (1988) Interactions of low density lipoprotein and other apolipoprotein B-containing lipoproteins with lipoprotein (a). J. Biol. Chem. 263, 6337-6343.

43. Camejo, G., Lopez, A., Lopez, F. \& Quinones, J. (1985) Interaction of low density lipoproteins with arterial proteoglycans: the role of charge and sialic acid content. Atherosclerosis $55,93-105$.

44. Vijayagopal, P., Srinivasan, S. R., Jones, K. M., Radhakrishnamurthy, B. \& Berenson, G. (1985) Complexes of lowdensity lipoproteins and arterial proteoglycan aggregates promote cholesteryl ester accumulation in mouse macrophages. Biochim. Biophys. Acta 837, 251-261.

45. Orekhov, A. N., Tertov, V. V., Mukhin, D. N., Koteliansky, V. E., Glukhova, M. A., Khashimov, Kh. A. \& Smirnov, V. N. (1987) Association of low density lipoprotein with particular connective tissue matrix components enhances cholesterol accumulation in cultured subendothelial cells of human aorta. Biochim. Biophys. Acta 928, 251-258. 
46. Falcone, D. J., Mateo, N., Shio, H., Minick, C. R. \& Fowler, S. D. (1984) Lipoprotein-heparin-fibronectin-denaturated collagen complexes enhance cholesteryl ester accumulation in macrophages. J. Cell. Biol. 99, 1266-1274.

47. Salonen, E.-M., Jauhiainen, M., Zardi, L., Vaheri, A. \& Ehnholm, C. (1989) Lipoprotein (a) binds to fibronectin and has serine proteinase activity capable of cleaving it. EMBO J. 8, 4035-4040.

48. Orekhov, A. N., Tertov, V. V., Mukhin, D. N., Koteliansky, V. E., Glukhova, M. A., Frid, M. G., Sukhova, G. K., Khashimov, Kh. A. \& Smirnov, V. N. (1989) Insolubilization of low density lipoprotein induces cholesterol accumulation in cultured subendothelial cells of human aorta. Atherosclerosis 79, 59-70.

49. Kokkonen, J. O. \& Kovanen, P. T. (1989) Proteolytic enzymes of mast cell granules degrade low density lipoproteins and promote their granule-mediated uptake by macrophages in vitro. J. Biol. Chem. 264, 10749-10755.
50. Kokkonen, J. O. (1989) Stimulation of rat peritoneal mast cells enhances uptake of low density lipoproteins by rat peritoneal macrophages in vivo. Atherosclerosis 79, 213223.

51. Kovanen, P. T. (1990) Atheroma formation: defective control in the intimal round-trip of cholesterol. Eur. Heart. J. $11,238-246$.

52. Klimov, A. N., Denisenko, A. D., Vinogradov, A. G., Nagornev, V. A., Pivovarova, Y. I., Sitnikova, O. D. \& Pleshkov, B. M. (1988) Accumulation of cholesteryl esters in macrophages incubated with human-antibody autoimmune complexes. Atherosclerosis 74, 41-46.

M. Jauhiainen
National Public Health Institute
Department of Biochemistry
Mannerheimintie 166
SF-00300 Helsinki

M. Jauhiainen

SF-00300 Helsinki 